\title{
Migration of Radiogenic Strontium during Metamorphism ${ }^{1}$
}

\author{
G. J. Wasserburg and A. L. Albee \\ Division of Geological Sciences \\ California Institute of Technology, Pasadena \\ M. A. LaNPhere \\ U. S. Geological Survey, Menlo Park, California
}

\begin{abstract}
Study of the concentration and isotopic composition of strontium and rubidium in hornblende diorite dikes and sills of Precambrian age from the Panamint Mountains of California showed that these rock systems were enriched in radiogenic $\mathrm{Sr}$ during a late Mesozoic metamorphism. Enrichments in radiogenic Sr were observed for total-rock samples which yielded apparent ages of up to $34,000 \mathrm{~m} . \mathrm{y}$., although there is no obvious petrographic evidence for such metasomatic changes. These results indicate that some caution is necessary in interpreting the $\mathrm{Sr}$ isotopic composition of rocks in terms of their original source or in assuming that 'total rocks' form closed systems. In general, the initial isotopic Sr composition should be determined, not assumed.
\end{abstract}

Introduction. This study is an investigation of the effects of relatively recent metamorphism on the isotopic composition of $\mathrm{Sr}$ and the concentration of $\mathrm{Sr}$ and $\mathrm{Rb}$ in some mafic igneous rocks of the Precambrian. The samples were chosen from an area in which Lanphere et al. [1963, 1964] had demonstrated that certain older Precambrian rocks had lost appreciable amounts of radiogenic $\mathrm{Sr}$ during a Mesozoic metamorphism.

The samples studied are from the Stone Corral area in Pleasant Canyon in the southern part of the Panamint Mountains of California. A sequence of later Precambrian rocks (the Pahrump series) unconformably overlies augen gneiss and crosscutting granite of the World Beater complex. The crystalline rocks occupy the core of an anticlinal dome and are cut by dioritic dikes, some of which can be traced into sills and dikes in the lower part of the overlying Pahrump sedimentary section. Middle-grade metamorphic mineral assemblages, characterized by the widespread occurrence of biotite and the local occurrence of andalusite, cordierite, garnet, and chloritoid, are developed in the mantling sedimentary rocks. However, the preservation of fine depositional features and the absence of metamorphic differentiation features

1 Contribution 1256, Division of Geological Sciences, California Institute of Technology, Pasadena. are suggestive of a lack of gross recrystallization or of significant mobilization and metasomatism. The mineral assemblages and textures in the augen gneiss, the granite, and the dioritic dikes and sills are not significantly affected by the metamorphism and might be interpreted reasonably as the primary mineralogy and texture. Details of the geology and petrography are given in the report by Lanphere et al. [1964].

The results from samples of the augen gneiss and granite from this area are that the $\mathrm{Sr}^{87} / \mathrm{Sr}^{88}$ and $\mathrm{Rb}^{\mathrm{B7}} / \mathrm{Sr}^{\mathrm{8}}$ ratios for the various component minerals of a particular sample lie on a straight line on the Sr evolution diagram, with a slope corresponding to an age of 100 to $150 \mathrm{~m} . \mathrm{y}$. This indicates that essentially complete $\mathrm{Sr}$ isotopic equilibration took place during Mesozoic regional metamorphism. While such mineral isochrons were found for several different rocks, it was found that the total-rock samples scattered rather widely and did not lie along an isochron. $\mathrm{Pb}-\mathrm{U}$ ages on zircon indicated primary ages of $1800 \mathrm{~m} . \mathrm{y}$. for the augen gneiss and $1350 \mathrm{~m} . \mathrm{y}$. for the granite, but nearly all the total-rock samples lay below a 1600-m.y. isochron, indicating younger apparent ages. These results showed that even total-rock samples as large as $85 \mathrm{~kg}$ were open to $\mathrm{Sr}$ or $\mathrm{Rb}$ transport during the period of isotopic redistribution. Apatite and plagioclase, which contain very little $R b$, showed large $\mathrm{Sr}^{67}$ enrichments; thus the observed effects must be attributed to Sr redistribution. 
The earlier data showed that the augen gneiss had lost radiogenic $\mathrm{Sr}$ and suggested that the granite had been enriched in radiogenic $\mathrm{Sr}$. It was expected, however, that more spectacular enrichments could be observed in the dioritic dikes and sills which have low $\mathrm{Rb} / \mathrm{Sr}$ ratios and which are in contact in many places with the World Beater complex, which contains rocks having high $\mathrm{Rb} / \mathrm{Sr}$ ratios.

Results. To have a basis for estimating the original undisturbed $\mathrm{Sr}$ isotopic compositions of the hornblende diorite dikes and sills, we obtained samples of 'Pahrump diabase' from localities outside the Stone Corral area. Mafic dikes and sills which are restricted to the lower part of the Pahrump series (Crystal Spring formation) throughout the Death Valley region are considered to be genetically related and of the same age [Wright, 1952]. These rocks are referred to as the 'Pahrump diabase,' although many of them are not petrographically of diabasic composition and texture. Geologic and geochronologic relations indicate that the 'Pahrump diabase' is between 600 and $1350 \mathrm{~m} . \mathrm{y}$. old. One sample (CP-440A) was obtained from a thick sill, intrusive into dolomite, in Warm Spring Canyon, about 10 miles southeast of the Stone Corral area. This area is immediately adjacent to the Silver Lady Canyon area studied by Wasserburg et al. [1959] and Silver et al. [1961], who reported ages in the pre-Pahrump basement complex of about $1700 \mathrm{~m} . \mathrm{y}$. by the $\mathrm{Ar}^{40}-\mathrm{K}^{40}, \mathrm{Sr}^{87}-\mathrm{Rb}^{87}$, and $\mathrm{Pb}-\mathrm{U}$ methods. Their data indicate that the rocks in this area are relatively undisturbed by any younger metamorphic episode. The other sample is from the Saratoga Springs area on the southeast edge of Death Valley, about 45 miles southeast of the Stone Corral area. K-Ar ages were measured on hornblende and pyroxene from the diabase in Warm Spring Canyon (CP-440A) in an attempt to verify that the diabase had not been disturbed by metamorphism and to date more precisely the 'Pahrump diabase.' The discrepancy between the ages (Table 1 ) indicates that the diabase has not remained undisturbed since its primary crystallization, as had been inferred from the results in Silver Lady Canyon. The 235-m.y. hornblende age is much less than the stratigraphic age of the diabase and indicates that the hornblende has lost radiogenic Ar. This Ar loss may be a metamorphic effect related to
TABLE 1. $\quad \mathrm{Ar}^{40}-\mathrm{K}^{40}$ Data

\begin{tabular}{|c|c|c|c|c|}
\hline Sample & $\begin{array}{l}\mathrm{K}, \\
\%\end{array}$ & $\begin{array}{c}A r^{40}{ }_{r a d}, \\
10^{-10} \mathrm{~mole} / g\end{array}$ & $\frac{A r^{40} \mathrm{rad}}{A r^{40}}$ & $\begin{array}{l}\text { Age, } \\
\text { m.y. }\end{array}$ \\
\hline $\begin{array}{l}\text { CP-440A } \\
\text { (horn- } \\
\text { blende) }\end{array}$ & $\begin{array}{l}1.198^{*} \\
1.212 \dagger\end{array}$ & 5.24 & 0.58 & 231 \\
\hline $\begin{array}{l}\text { CP-440A } \\
\quad \text { (pyroxene) }\end{array}$ & $\begin{array}{l}0.0939^{*} \\
0.0920 \dagger\end{array}$ & 1.73 & 0.34 & 840 \\
\hline
\end{tabular}

* Analysis by flame photometer.

$\uparrow$ Analysis by isotope dilution.

Mesozoic intrusive activity or to Tertiary extrusive activity, both of which occurred in this region. The $840-\mathrm{m} . \mathrm{y}$. pyroxene age lies within the stratigraphic-geochronologic restrictions and might be considered a reasonable, or at least a minimum, age for the diabase. However, Hart and Dodd [1962] have shown that pyroxenes in metamorphic rocks may contain excess radiogenic $\mathrm{Ar}$, which results in high ages. Thus, we must conclude that our $\mathrm{K}$-Ar results do not establish the age of the 'Pahrump diabase' in Warm Spring Canyon.

Analyses of samples of 'total rock' and of mineral separates are reported in Table 2 and shown in Figure 1. The 'total rock' sample for CP-436 was $5 \mathrm{~kg}$, but all others were hand specimen size. In the last column of Table 2 an 'apparent age' is given, based on an assumed initial $\mathrm{Sr}^{37} / \mathrm{Sr}^{88}$ ratio of 0.703 . The raw $\mathrm{Sr}$ isotopic data were normalized to a $\mathrm{Sr}^{88} / \mathrm{Sr}^{88}$ ratio of 0.1194 . An $83 \% \mathrm{Sr}^{84}$ tracer was used. The $\mathrm{Sr}^{87} / \mathrm{Sr}^{80}$ ratios for the samples are tabulated from both composition runs and spiked runs in several cases. The concentrations of $\mathbf{S r}$ and $\mathrm{Rb}$ are considered accurate to within 0.7 and $2 \%$, respectively. The $\mathrm{Rb}, \mathrm{Sr}$, and $\mathrm{K}$ analyses reported in this work were done at the California Institute of Technology. The Ar analyses were done by one of us (M.L.) in the laboratory of the United States Geological Survey. The K analyses were done by both flame photometry and isotope dilution [Wasserburg et al., 1962].

The apparent initial Sr isotopic composition of the two diabase samples from outside the Stone Corral area is certainly different. The initial $\mathrm{Sr}^{87} / \mathrm{Sr}^{89}$ ratio of TSS- 1 is 0.708 , corresponding to the value measured for the apatite, which is nearly Rb-free. Sample CP-440A 
TABLE 2. Sr and Rb Data

\begin{tabular}{|c|c|c|c|c|c|c|}
\hline Sample & Rock or Mineral & $\begin{array}{l}\text { Normal Sr, } \\
10^{-6} \mathrm{~mole} / \mathrm{g}\end{array}$ & $\begin{array}{c}\mathrm{Rb}, \\
10^{-6} \mathrm{~mole} / \mathrm{g}\end{array}$ & $\mathrm{Sr}^{87} / \mathrm{Sr}^{86}$ & $\mathrm{Rb}^{87} / \mathrm{Sr}^{80}$ & $t \times 10^{9}$, years \\
\hline CP-440A & $\begin{array}{l}\text { Sill, total-rock } \\
\text { plagioclase }\end{array}$ & $\begin{array}{l}4.141 \\
3.126\end{array}$ & $\begin{array}{l}0.170 \\
0.0198\end{array}$ & $\begin{array}{l}0.7047 \\
0.7032 \\
0.7030\end{array}$ & $\begin{array}{l}0.1159 \\
0.0179\end{array}$ & $(1.09)$ \\
\hline TSS-1 & $\begin{array}{l}\text { Dike, total-rock } \\
\text { apatite }\end{array}$ & $\begin{array}{l}2.284 \\
4.864\end{array}$ & $\begin{array}{l}0.718 \\
0016\end{array}$ & $\begin{array}{l}0.7170 \\
0.7168 \\
0.7078 \\
0.7078\end{array}$ & $\begin{array}{l}0.8876 \\
0.0091\end{array}$ & \\
\hline CP-436 & $\begin{array}{l}\text { Dike, total-rock } \\
\text { plagioclase }\end{array}$ & $\begin{array}{l}0.945 \\
3.24\end{array}$ & $\begin{array}{l}0.058 \\
0.091\end{array}$ & $\begin{array}{l}0.8040 \\
0.8046\end{array}$ & $\begin{array}{l}0.175 \\
0.0799\end{array}$ & $\begin{array}{l}32.8 \\
59.0\end{array}$ \\
\hline CP-349 & Dike, total rock & 1.696 & 0.039 & 0.7427 & 0.0655 & 34.1 \\
\hline CP-409b & $\begin{array}{l}\text { Cobble in conglomerate, } \\
\text { total rock }\end{array}$ & 1.571 & 3.451 & 0.7764 & 6.200 & 0.85 \\
\hline CP-263 & Sill, total rock & 4.357 & 0.0994 & 0.7415 & 0.0644 & 33.7 \\
\hline CP-155 & $\begin{array}{l}\text { Dike, total rock } \\
\text { Plagioclase }\end{array}$ & 7.823 & $\begin{array}{l}0.792 \\
0.270\end{array}$ & $\begin{array}{l}0.7273 \\
0.7298 \\
0.7261 \\
0.7231\end{array}$ & $\begin{array}{l}1.077 \\
0.0975\end{array}$ & $\begin{array}{l}1.61 \\
15.3\end{array}$ \\
\hline CP-156 & Sill, total rock & 5.176 & 0.295 & $\begin{array}{l}0.7223 \\
0.7217\end{array}$ & 0.161 & 8.15 \\
\hline $\mathrm{CP}-70 \mathrm{C}$ & $\begin{array}{l}\text { Flow, total-rock } \\
\text { calcite } \\
\text { Plagioclase }\end{array}$ & $\begin{array}{l}1.573 \\
2.91\end{array}$ & $\begin{array}{l}0.479 \\
0.242\end{array}$ & $\begin{array}{l}0.7191 \\
0.7190 \\
0.7179 \\
0.7176 \\
0.7177\end{array}$ & $\begin{array}{l}0.859 \\
0.234 \\
0.214\end{array}$ & 1.33 \\
\hline CP-426-1 & $\begin{array}{l}\text { Dolomite clast } \\
\text { Dolomite clast }\end{array}$ & $\begin{array}{l}3.69 \\
6.78\end{array}$ & $\begin{array}{l}0.0054 \\
<0.2\end{array}$ & $\begin{array}{l}0.7080 \\
0.7098 \\
0.7218\end{array}$ & 0.0041 & \\
\hline CP-151 & $\begin{array}{l}\text { Dolomite, total rock } \\
\text { (Beck Springs) }\end{array}$ & & & 0.7101 & & \\
\hline
\end{tabular}

$\lambda \mathrm{Rb}^{87}=1.39 \times 10^{-11}$ year $^{-1}$

has an initial $\mathrm{Sr}^{87} / \mathrm{Sr}^{86}$ ratio of 0.703 , corresponding to the value measured for the plagioclase, which also is nearly $\mathrm{Rb}$-free. The difference may be truly original, or the higher value may reflect the effect of metamorphism or deuteric alteration. Nevertheless, both values are well within the range obtained for 'normal' basalts [Faure and Hurley, 1963], and we infer that they represent the probable range in original $\mathrm{Sr}$ composition of the dioritic dikes and sills in the Stone Corral area.

The samples from the Stone Corral area fall into three groups and are located with respect to the geologic map in Lanphere et al. [1964]. The first group is from the southeast corner of the World Beater dome, south of the road up Pleasant Canyon. Samples CP-436 and CP349 were collected about 0.3 mile apart from a hornblende diorite dike, 5 meters thick, which crosscuts the World Beater complex. Sample CP-263 is from a sill about 250 feet above the uncomformity at the base of the Pahrump series and in the vicinity of the dike. It is presumed that the dike is a feeder to the sill, although this particular dike has not actually been traced into the sill. CP-409b is a mafic cobble from a conglomerate between the sill and the unconformity; the cobble consists of biotite, garnet, plagioclase, and ilmenite.

The total-rock sample and the plagioclase 


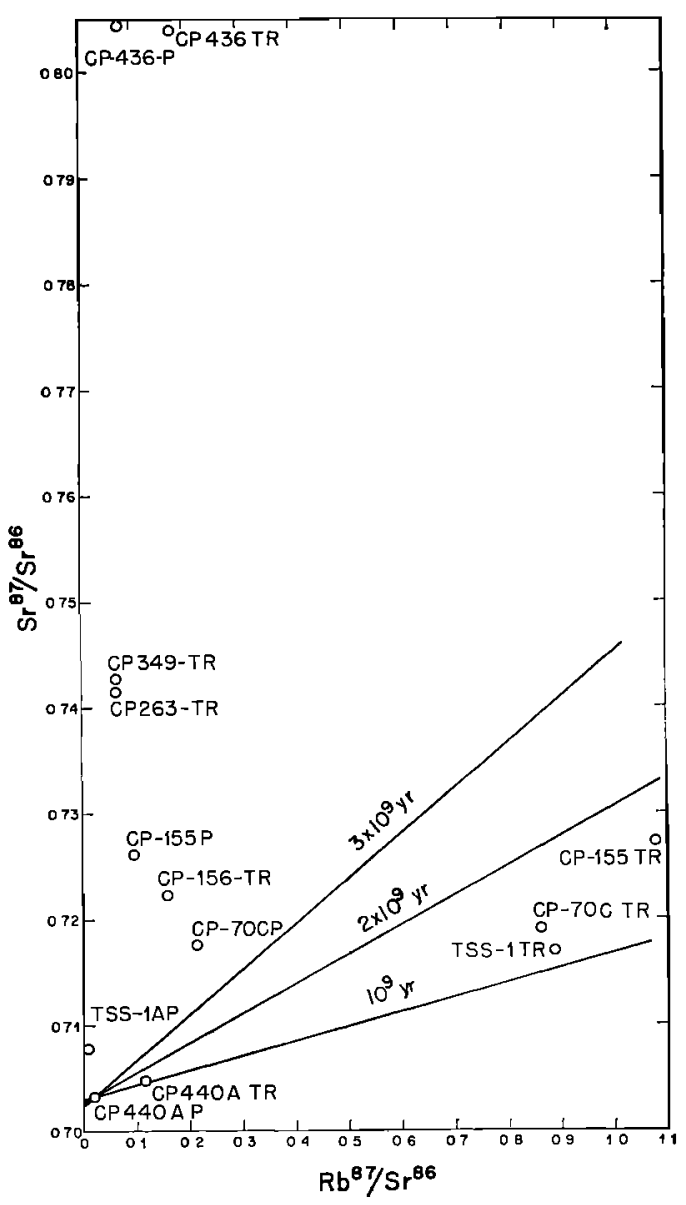

Fig. 1. Strontium evolution diagram showing the data for total-rock samples and minerals from dikes and sills.

separate from CP-436 have the same Sr isotopic composition, the $\mathrm{Sr}^{87}$ being $14 \%$ enriched. The total rock has a higher $\mathrm{Rb}^{87} / \mathrm{Sr}^{86}$ ratio because of the presence of other more Rb-rich phases. The apparent age of the plagioclase is twice that of the total rock as a direct consequence of the smaller $\mathrm{Rb}^{87} / \mathrm{Sr}^{80}$ ratio. This general pattern is seen for the other samples as well. Both the ages are absurdly high and exceed by a factor of 8 or more the presently accepted age of the earth.

An $\mathrm{Ar}^{40}-\mathrm{K}^{40}$ age of $377 \mathrm{~m} . \mathrm{y}$. was determined from the hornblende of this rock [Lanphere et al., 1964] indicating that there was a partial loss of radiogenic Ar during the metamorphism. The total-rock analysis of the other sample from this same dike (CP-349) and of the sill (CP-263), which appears to be associated with this dike, also shows a distinct enrichment in $\mathrm{Sr}^{\mathrm{Bz}}$ and yields excessively high ages, indicating addition of radiogenic Sr. The enrichment in $\mathrm{Sr}^{87}$ in these rocks is distinctly above the values expectable for undisturbed Rb-poor systems, but the enrichment is below that obtained in the neighboring $\mathrm{Rb}$-rich augen gneiss and granite, which have $\mathrm{Sr}^{87} / \mathrm{Sr}^{88}$ values of 0.85 to 1.09 [Lanphere et al., 1964].

The sample of the cobble from a conglomerate between the sill and the unconformity has a similar $\mathrm{Sr}^{87} / \mathrm{Sr}^{89}$ ratio, but because it has a much greater $\mathrm{Rb}$ content it yields a total-rock apparent age of $850 \mathrm{~m} . \mathrm{y}$.

The second group of samples is from the northeastern corner of the World Beater dome, southwest of Sentinel Peak and about 3 miles north of the location of the first sample group. A hornblende diorite dike, lithologically similar to the first dike, has been traced for over a mile within the World Beater complex, across the unconformity, and into a hornblende diorite sill. Sample CP-156 is a sample from the sill, very high in coarse-grained hornblende, and sample CP-155 is from the dike, which is nearly a mile from the sill along the strike of the dike. The analyses show a pattern similar to that shown by the first group from the southern part of the area. The total-rock sample of the dike is only $3 \%$ enriched in $\mathrm{Sr}^{87}$ and because of a relatively high $\mathrm{Rb}$ content yields an apparent age of 1.61 b.y. This is, perhaps, considering the errors, reasonable in comparison with $\mathrm{Pb}-\mathrm{U}$ ages of 1800 m.y. for the augen gneiss and 1350 m.y. for the granite. However, the plagioclase separate has an almost identical $\mathrm{Sr}^{57} / \mathrm{Sr}^{80}$ ratio, in spite of the fact that the $\mathrm{Rb}^{87} / \mathrm{Sr}^{88}$ ratio is a factor of 10 smaller. The slight difference between the isotopic compositions of the plagioclase and the total rock is what would be expected from the radioactive decay of $\mathrm{Rb}^{87}$ over the past 100 to $150 \mathrm{~m} . \mathrm{y}$. Since the plagioclase has a much higher $\mathrm{Sr}^{87} / \mathrm{Sr}^{88}$ ratio than that found for the undisturbed rocks, we must conclude that the plagioclase in this rock has been enriched in $\mathrm{Sr}^{27}$ during metamorphism.

The related sill (CP-156) also shows an enrichment, although it is not as marked as in some of the other samples. This anomaly is small enough so that it might have been er- 
roneously interpreted to be due to an abnormally high $\mathrm{Sr}^{87} / \mathrm{Sr}^{89}$ ratio in the original magma.

CP-70C is from a mafic flow within the Kingston Peak formation of the Pahrump series, about 1 mile east of the World Beater dome and about 3000 feet stratigraphically above the World Beater complex. The flow is about 120 feet thick and contains pillow-like structures through most of the thickness. CP-70C is a amygduloidal rock consisting of plagioclase laths in a fine-grained aggregate of chlorite, calcite, and ilmenite; the amydules are chlorite and calcite with minor quartz. A total-rock sample and separates of plagioclase and calcite were analyzed. It was not possible to obtain a really pure separate of the calcite, and its abnormally high $\mathrm{Rb}$ content is due to fine inclusions of biotite. The total rock yields an apparent age, which lies within the stratigraphicgeochronologic restrictions-although outside our prejudices. However, the results from the mineral separates again indicate that the system is badly disturbed. All three samples have essentially the same $\mathrm{Sr}$ isotopic composition, in spite of a wide range in $\mathrm{Rb}^{87} / \mathrm{Sr}^{88}$, indicating that only a short decay time could have ocurred since the disturbance.

Since the previous data indicated that $\mathrm{Sr}^{87}$ enrichment had occurred at a considerable distance from the World Beater complex, it was decided to look for evidence of really major enrichment in the overlying sedimentary rocks, such as would be necessary to enrich a whole sedimentary carbonate unit. Samples of carbonate rock were taken from several stratigraphic positions. Sample CP-151 is a sample of dolomite from the Beck Spring dolomite of the Pahrump series, collected at least 600 feet stratigraphically above the World Beater complex, and samples CP-426-1 and 2 are dolomite clasts from the Kingston Peak formation, collected about 1000 feet stratigraphically above the World Beater complex. CP-151 seems to have a normal $\mathrm{Sr}$ composition for dolomite of that age. CP-426-1 also has a normal $\mathrm{Sr}$ isotopic composition, but CP-426-2 shows an enrichment which is considerably greater than could be explained by the in situ decay of Rb. The matrix of the conglomerate contains abundant biotite formed during the 100 - to $150-\mathrm{m} . y$. metamorphism and the excess radiogenic Sr of the clast may be very locally derived.
It is important to compare the character of the 'Pahrump diabase' in the disturbed and undisturbed areas. The samples from the Warm Spring and Saratoga Spring localities are both typical 'deuterically altered diabase'; they consist of 65 to $75 \%$ plagioclase in interlocking blades 5 to $10 \mathrm{~mm}$ in length, about 20 to $30 \%$ interstitial clinopyroxene, about $5 \%$ ilmenite, and about $1 \%$ apatite in elongate rods. The plagioclase is zoned, and is multiply and complexly twinned; it is extensively saussuritized with abundant clinozoisite in an albite matrix. The clinopyroxene has been almost completely altered to pseudomorphic aggregates of uralitic amphibole, clinozoisite, calcite, chlorite, and green biotite - only rare relics of clinopyroxene persist.

In contrast, the dioritic dikes of the Stone Corral area consist of about 60 to $65 \%$ hornblende in interlocking blades about $0.5 \mathrm{~mm}$ in length, about 30 to $35 \%$ plagioclase (An 32), 3 to $5 \%$ ilmenite, and less than $1 \%$ apatite. They may also contain as much as 2 to $3 \%$ biotite, clinozoisite, quartz, calcite, and chlorite. The plagioclase is untwinned, has a rather undulose extinction, and contains very little trace of alteration products. The hornblende contains no pyroxene cores but is itself somewhat altered on its margins to fine needles of actinolite. Hornblende is more abundant in the sills, which may consist almost entirely of interlocking hornblende blades, 2 to $3 \mathrm{~cm}$ across, peripherally altered to fine needles of actinolite, biotite, chlorite, clinozoisite, and carbonate, with about 5\% interstitial plagioclase and 3\% ilmenite. It is of interest to note that the isotopic Sr composition has not been changed in the rocks which show obvious alteration, whereas the isotopic composition has been extensively changed in rocks which on the basis of both field relations and petrographic examination might have been classed as post-metamorphic hornblende diorite dikes. The contacts are sharp and the dikes are undeformed over distances of up to a mile. The absence of zoning or of twinning in the plagioclase and the lack of alteration might suggest a metamorphic origin, but the 'diabasic' texture and the lack of clinozoisite might argue against a metamorphic origin. It is only by the correlation and petrographic comparison with the unmetamorphosed but highly altered 'Pahrump diabase' that the meta- 
morphic origin of the mineral assemblage is made clear.

Conclusions. Excessive ages were obtained in this study on total-rock samples of dioritic composition in a Precambrian terrane which has undergone Mesozoic metamorphism. Many samples yielded ages that are patently absurd. Genetically related rocks of similar lithology from relatively undisturbed areas give initial $\mathrm{Sr}^{87} / \mathrm{Sr}^{88}$ ratios which are normal, indicating that it is reasonable to assume that the initial $\mathrm{Sr}$ isotopic composition of the anomalous rocks was normal. To obtain reasonable ages from these total-rock data it would be necessary to assume initial $\mathrm{Sr}^{87} / \mathrm{Sr}^{80}$ ratios which are far in excess of that reported for any igneous rock, either mafic or felsic in composition. The data for the total rocks and some of their constituent mineral phases indicate that only a relatively short time (about $10^{8} \mathrm{yr}$ ) could have elapsed since the mineral constituents had the same $\mathrm{Sr}^{87} / \mathrm{Sr}^{80}$ composition. For CP-155, in particular, a maximum age of only $200 \mathrm{~m} . \mathrm{y}$. can be calculated for a total-rock-plagioclase isochron, using the extreme possible errors.

The data for the individual mineral phases demonstrate that the process certainly involved the transport of Sr. The relative abundance of $\mathrm{Rb}$ and $\mathrm{Sr}$ in these rocks is comparable with that found in undisturbed dioritic rocks, and it is not unreasonable to attribute the observed effects to the migration of $\mathrm{Sr}^{87}$. The anomalous enrichments of $\mathbf{S r}^{87}$ which were observed correspond to the addition of up to $1 \mathrm{ppm}$ of pure radiogenic $\mathrm{Sr}^{87}$.

From the study of the World Beater complex [Lanphere et al., 1963, 1964], it is clear that a chemical exchange process has occurred on a local scale (about $10 \mathrm{~cm}$ ), since the $\mathrm{Sr}$ has been isotopically equilibrated between the mineral phases within the augen gneiss and the granite. The mineral phases were in isotopic equilibrium with one another and have equilibrated with the local total-rock Sr reservoir at about 100 m.y. It therefore follows that relatively unhindered $\mathrm{Sr}$ mobilization took place locally for all phases in these rocks during metamorphism, rather than the simple occlusion of radiogenic Sr by particular phases. The data on the mineral phases and total-rock samples of the mafic dikes show that the $\mathbf{S r}$, including an anomalous radiogenic component, was isotopically homogenized in the different minerals. While it might be possible to account for the $\mathrm{Sr}^{87}$ anomalies in the dike rocks by the addition of pure $\mathrm{Sr}^{87}$ during metamorphism, followed by subsequent local homogenization, it is more reasonable in the light of the demonstrated mobility of $\mathrm{Sr}$ on the local scale to suggest that the enrichment occurred by a similar metasomatic exchange process but on a somewhat larger scale. If the anomalies in $\mathrm{Sr}^{87} / \mathrm{Sr}^{80}$ are due to addition or exchange of average total-rock $\mathrm{Sr}$ of the basement complex with normal $\mathrm{Sr}$ of the diorite dikes, an addition of about $20 \mathrm{ppm}$ would be required. This amount represents a significant contribution to the presumed original $\mathrm{Sr}$ content and is possibly indicative of gross metasomatic changes in the major chemical constituents. Despite this isotopic evidence of exchange, the dike contacts are sharp and give no suggestion that such an exchange has occurred.

The isotopically disturbed systems occur in an area of Mesozoic middle-grade metamorphism which involved a relatively old Precambrian basement containing highly radiogenic $\mathrm{Sr}$. These rocks show no definitive evidence of metasomatism, as deduced from field and petrographic studies. The significance of these results is that they demonstrate that total-rock systems may be open during metamorphism and that these systems may take on a $\mathrm{Sr}$ isotopic composition which is completely secondary without the concurrent production of gross petrographic effects. It is clear that the $\mathrm{Sr}$ isotopic composition of a total-rock sample may not be assumed to be indicative of the original source of igneous and metamorphic rocks unless it can be demonstrated that this ratio is unaffected by secondary processes. Also, any $\mathrm{Rb} / \mathrm{Sr}$ age based on an assumed initial $\mathrm{Sr}$ value may be suspect, and there is, in general, a need to demonstrate the initial value for such age measurements.

Acknowledgments. We would like to thank Mr. B. Troxel of the California Bureau of Mines for his very kind efforts in obtaining some samples of diabase.

This work was supported by grants from the National Science Foundation and the Atomic Energy Commission.

\section{REFERENCES}

Faure, G., and P. M. Hurley, The isotopic composition of strontium in oceanic and continental 
basalts; application to the origin of igneous rocks, J. Petrol. 4, 31-50, 1963.

Hart, S. R., and R. T. Dodd, Jr., Excess radiogenic argon in pyroxenes, J. Geophys. Res., 67, 2998$2999,1962$.

Lanphere, M. A., G. J. Wasserburg, A. L. Albee, and G. R. Tilton, Isotopic and petrologic study of the reconstitution of Precambrian gneiss of the Panamint Range, California, during Cretaceous time (abstract) Geol. Soc. Am. Spec. Paper 73 (1962 meetings), p. 193, 1963.

Lanphere, M. A., G. J. Wasserburg, A. L. Albee, and G. R. Tilton, Redistribution of $\mathrm{Sr}$ and $\mathrm{Rb}$ isotopes during metamorphism, World Beater complex, Panamint Range, California, Isotopic and Cosmic Chemistry, North-Holland Publishing Company, Amsterdam, 1964.
Silver, L. T., C. R. McKinney, and L. A. Wright, Some Precambrian ages in the Panamint Range, Death Valley, Calif. (abstract), Geol. Soc. Am. Spec. Paper 68, p. 55, 1961.

Wasserburg, G. J., G. W. Wetherill, and L. A. Wright, Ages in the Precambrian terrane of Death Valley, California, J. Geol., 67, 702, 1959. Wasserburg, G. J., R. E. Zartman, and T. Y. Wen, Potassium determinations on amphiboles by flame photometry and isotope dilution (abstract), J. Geophys. Res., 67, 3607, 1962.

Wright, L. A., Geology of the Superior Talc area, Death Valley, California, Calif. Div. Mines Spec. Rept. 20, 1962.

(Manuscript received April 20, 1964; revised July 2, 1964.) 